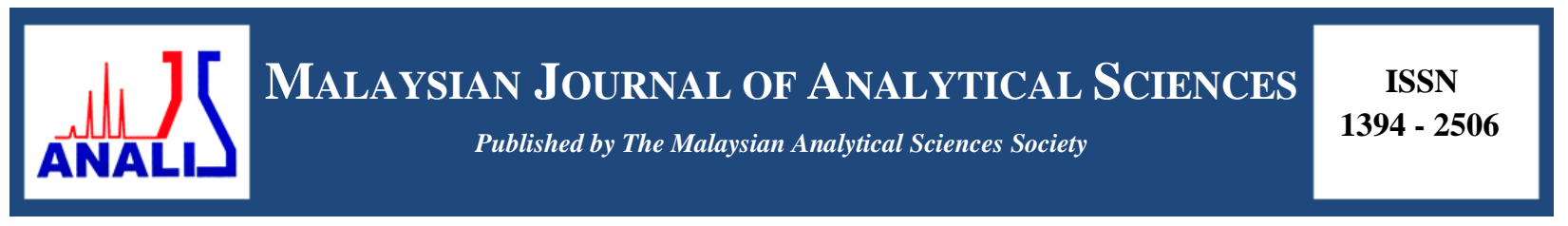

\title{
ELECTROSPUN POLY (VINYL ALCOHOL) NANOFIBERS DOPED WITH MESOPOROUS SILICA NANOPARTICLES FOR CONTROLLED RELEASE OF HYDROPHILIC MODEL DRUG
}

\author{
(Elektrospun Poli(Vinil Alkohol) Nanofiber Didopkan Dengan Silika Nanopartikel Berliang \\ Meso untuk Perlepasan Terkawal Model Dadah Hidrofilik)
}

\author{
Nur Izzah Md Fadilah ${ }^{1}$, Haslina Ahmad ${ }^{1,2}$, Mohd Firdaus Abd Rahman ${ }^{3}$, Norizah Abdul Rahman ${ }^{2}$ \\ ${ }^{1}$ Integrated Chemical Biophysics Research \\ ${ }^{2}$ Department of Chemistry, Faculty of Science \\ ${ }^{3}$ Institute of Advanced Technology \\ Universiti Putra Malaysia, 43400 UPM Serdang, Selangor, Malaysia \\ *Corresponding author: haslina_ahmad@upm.edu.my
}

Received: 19 August 2018; Accepted: 10 March 2019

\begin{abstract}
Nanofiber materials have often been reported as transporters for clinical drugs but face the limitation of burst releasing the drugs. Therefore, mesoporous silica nanoparticles (MSNs) have raised much interest to be used in drug delivery system because of their large pore volume and high surface area. In this study, nanofiber drug delivery system based on poly(vinyl alcohol) (PVA) loaded with novel ionic liquid templated MSNs were successfully prepared by the electrospinning method. The composite fiber mat was designed for the prolonged and sustained release of drug. MSNs were synthesized by co-condensation method with average particles size of $\sim 70 \mathrm{~nm}$ and then loaded with hydrophilic model drug methylene blue (MB). The effect incorporation of MB-loaded MSNs into the polymer solution to form fibrous structure was investigated. Uniform PVA/MB nanofiber mat was also produced as controls. The morphologies of nanoparticles and composite nanofiber were characterized by field emission scanning electron microscope (FESEM). After electrospinning, electron microscope revealed that MSNs were randomly distributed in the regions of nanofiber. Drug release profiles of MB from MSNs and electrospun mats were evaluated. The results indicated that adsorption of model drug MB into MSNs and incorporation them into nanofiber are effective way of minimizing burst release of drug. Sustained delivery was achieved with controllable release during the $120 \mathrm{~h}$ releasing period
\end{abstract}

Keywords: poly(vinyl alcohol), mesoporous silica nanoparticles, nanofiber, electrospinning, drug delivery

\begin{abstract}
Abstrak
Bahan nanofiber sering dilaporkan sebagai penghantar untuk ubat-ubat klinikal tetapi ia menghadapi limit batasan dalam melepaskan ubat secara pecah. Oleh itu, silika nanopartikel berliang-meso (SMN) telah menimbulkan tarikan untuk digunakan dalam sistem penghantaran ubat-ubat kerana memiliki isipadu liang yang besar dan kawasan permukaan yang tinggi. Dalam kajian ini, sistem penghantaran ubat iaitu nanofiber yang berdasarkan poli(vinil alkohol) (PVA) dimuatkan bersama SMN cecair ionik baru telah berjaya disediakan melalui kaedah putaran elektro. Komposit tikar fiber telah direka untuk pembebasan ubat yang berpanjangan dan berterusan. SMN telah disintesis oleh kaedah pemeluwapan bersama dengan purata saiz partikel $\sim 70 \mathrm{~nm}$ dan kemudian, dimuatkan dengan model hidrofilik ubat iaitu metilina biru (MB). Kesan penggabungan BM-SMN ke dalam polimer untuk membentuk struktur fiber telah dikaji. Nanofiber PVA/BM yang seragam juga dihasilkan sebagai kawalan. Morfologi nanopartikel dan komposit nanofiber telah dicirikan oleh mikroskop elektron pengimbasan pelepasan medan (MMEPP). Selepas putaran elektro, mikroskop elektron mendedahkan bahawa SMN berada secara rawak di dalam nanofiber. Profil pembebasan ubat BM dari SMN dan tikar putaran elektro telah dinilai. Keputusan menunjukkan bahawa penyerapan model ubat BM ke dalam SMN dan seterusnya memasukkannya ke nanofiber adalah cara yang berkesan untuk meminimumkan
\end{abstract}




\section{Nur Izzah et al: ELECTROSPUN POLY (VINYL ALCOHOL) NANOFIBERS DOPED WITH MESOPOROUS SILICA NANOPARTICLES FOR CONTROLLED RELEASE OF HYDROPHILIC MODEL DRUG}

pembebasan ubat secara pecah. Penghantaran yang berterusan telah dicapai dengan pembebasan yang dapat dikawal dalam tempoh 120 jam.

Kata kunci: poli(vinil alkohol), silika nanopartikel berliang-meso, nanofiber, elektrospining, penghantaran ubat

\section{Introduction}

In recent years, sustained and slow release of drugs has gained much attention towards the development of drug delivery systems (DDS). By designing DDS which can avoid burst release of drug as well as to protect normal tissue and healthy organs are becoming very crucial. The system includes minimizing the frequency of dosing, prolonging the period of the drug and providing a constant drug level. Hence, the therapeutic efficacies have been improved and could overcome the adverse side effects. Recently, a number of different carriers have been studied in order to control drug release such as micelles [1,2], liposomes [3], biocompatible nanoparticles and electrospun nanofiber [4].

The nanofibers were widely produced by electrospinning method, in which fibers forming a matrix with interconnected pores through a polymer jet with the use of electric field [5]. Recently, drug is direct mixed to the polymer solution and blended before electrospinning. However, the electrospun mats for this approach could affect the burst release profile where the drugs were distributed throughout the volume of polymer solution. In order to overcome this problem, the encapsulating of the drugs in nanoparticles and incorporation of nanoparticles into random electrospun nanofiber has been employed. For instance, Jalvandi et al. [6] reported approximately $70 \%$ of levofloxacin (LVF) in the nanoparticles was release in burst fashion throughout the first 20 min compared to $45 \%$ of LVF released from core shell nanofiber in the first day. Song et al [7] were studied designed a co-delivery system based on poly(lactic-co-glycolic acid)(PLGA) and nanoparticles for drug delivery applications. Therefore, incorporation of nanoparticles into the polymer matrix has gained attention.

Mesoporous silica nanoparticles (MSNs) are one of the potential nanoparticles that have been used as a nanocarrier for drugs. MSNs have shown advantages and unique properties such as high specific surface area, large pore volumes and good biocompatibility with no cytotoxicity [8] therefore, it could provide an alternative method for encapsulation of drugs and thus incorporation into polymer nanofiber. Considering significant advantages of MSNs, we had successfully synthesized MSNs by using novel 1-hexadecylpyridinium bromide $\left(\mathrm{C}_{16} \mathrm{PyBr}\right) \mathrm{IL}$ as a template, then incorporated MSNs into poly(vinyl alcohol) (PVA) electrospun nanofiber produced by electrospinning technique. In this study, the key issue for preparing polymeric-inorganic nanoparticle fiber is the dispersion of MSNs in a polymer matrix uniformly while aggregation is avoided. Finally, the successfully fabricated electropun nanofiber/MSNs were investigated on release study by using methylene blue (MB) as a hydrophilic model drug.

\section{Materials}

\section{Materials and Methods}

Poly(vinyl alcohol) (PVA, MW 90000) was purchased from Nippon Gohsei Singapore Pte Ltd. All other chemicals used in the experiments were of analytical grade and used without further purification.

\section{Synthesis of MSNs}

Briefly, $0.5 \mathrm{~g}$ of ionic liquid template $\left(\mathrm{C}_{16} \mathrm{PyBr}\right)$ was dissolved completely in $20 \mathrm{~mL}$ deionized water. The mixture was stirred at $750 \mathrm{rpm}$ and maintained at $90{ }^{\circ} \mathrm{C}$ for 1 hour. Then, $2.0 \mathrm{~mL}$ TEOS and $60 \mu \mathrm{L}$ TEA were added dropwise with the rate of $1 \mathrm{~mL} / \mathrm{min}$ to the above solution. The reaction was continuous stirring for another 1 hour. After the reaction completed, solution was cooled to room temperature. The synthesized nanoparticles were then centrifuged and further reflux in a mixture of $3 \mathrm{~mL} \mathrm{HCl}$ and $60 \mathrm{~mL}$ ethanol under $90{ }^{\circ} \mathrm{C}$ for 24 hours to remove the template. The products were collected via centrifugation at $6000 \mathrm{rpm}$ for 15 minutes and washed with ethanol several times to remove excess reactants. Finally, the obtained MSNs were dried in the oven at $60{ }^{\circ} \mathrm{C}$ for 24 hours.

\section{Fabrication of MB-loaded MSNs}

In order to prepare MB-loaded MSNs, $0.05 \mathrm{~g}$ of MSNs were soaked into $10 \mathrm{~mL}$ PBS that containing $0.1 \mathrm{mg} / \mathrm{mL}$ of MB. The solution was stirred in the dark place for 24 hours. The mixture was separated by centrifugation at 6000 rpm about 15 minutes. Finally, MB-loaded MSNs were dried at $60{ }^{\circ} \mathrm{C}$ for 24 hours to reach a constant weight. The 
amount of MB loading into the MSNs was measured by determining their corresponding concentration difference in the medium before and after loading. The drug loading efficiency was calculated by using the following equation 1 :

$$
\text { Drug loading ef ficiency }(\%)=\frac{\text { total amountme-fres amount } M B}{\text { total a mount } M B} \times 100
$$

\section{Fabrication of PVA/MB-loaded electrospun mat}

An amount of MB-loaded MSNs which is $30 \mathrm{mg}$ was first ultrasonically dispersed into the mixed solution of $4 \mathrm{~mL}$ deionized water and $1 \mathrm{~mL}$ acetone for 30 minutes. Then, $10 \mathrm{wt} . \%$ of PVA polymer was added and stirred at $80{ }^{\circ} \mathrm{C}$ to form a homogeneous solution. The electrospinning conditions were conducted as follows. Then, appropriate amount of citric acid as a crosslinking agent was added to the polymer solution. The electrospinning conditions were conducted as follows. The applied voltage on the needle of the syringe was controlled at $15 \mathrm{kV}$, the rate of the polymer solution was fixed at $0.8 \mathrm{~mL} / \mathrm{h}$, and the distance between the tip of needle and the collector was $15 \mathrm{~cm}$.

\section{Characterization}

TEM images were taken on a Tecnai G2 F20 electron microscope with an acceleration voltage of 200kV. BET surface area, average pore volume and average pore diameter of the nanoparticles were measured by physisorption of $\mathrm{N}_{2}$ at $77 \mathrm{~K}$ over a Micromeritics ASAP 2020. Before measurement, the samples were degassed at $200{ }^{\circ} \mathrm{C}$ for 6 hours to remove moisture and adsorbed gas. The morphology observation was performed using FESEM (JEOL JSM-6700F, Japan). One hundred selected fibers randomly from the images were measured and analyzed using image analysis software to determine the fiber size distributions.

\section{In vitro drug release}

The in vitro drug release studies were achieved in phosphate buffer saline (PBS, $\mathrm{pH}$ 7.4) at room temperature over 120 hours period of time. The $0.005 \mathrm{~g}$ MB-loaded MSNs and electrospun fiber were incubated and immersed in 10 $\mathrm{mL}$ PBS, separately. After that, $1 \mathrm{~mL}$ of the release buffer was taken out at determined time intervals for analysis and replaced with the same volume of fresh buffer. The electrospun nanofiber was taken out after immersion step and rinsed with abundant distilled water to remove the residual buffer. Then, it was freeze-dried for 2 days and the morphological change after drug release was observed by FESEM. The concentration of MB was determined by using UV-Vis spectrophotometer at $663.50 \mathrm{~nm}$. The cumulative release was calculated based on the standard calibration curve.

\section{Results and Discussion}

The morphology and structure of MSNs and MB-loaded MSNs

Figure 1(a) and 1(b) showed FESEM and TEM images of the synthesized of bare MSNs, respectively. It can be seen that MSNs are approximately spherical in shape with uniform size of $\sim 70 \mathrm{~nm}$. Also, the nanoporous channels were clearly observed in the inner of MSNs. As shown in Figure 1(c), the $\mathrm{N}_{2}$ adsorption-desorption isotherms confirmed the well-ordered mesoporous structure of MSNs and MB-loaded MSNs The properties of BET surface area, pore diameter, pore volume of the MSNs and MB-loaded MSNs also drug loading efficiency were shown in Table 1 . The MSNs possessed average pore size about $5.5 \mathrm{~nm}$, and the amount of MB loaded into MSNs was $91.9 \%$. Therefore these MSNs have promising to be used as drug delivery agent.
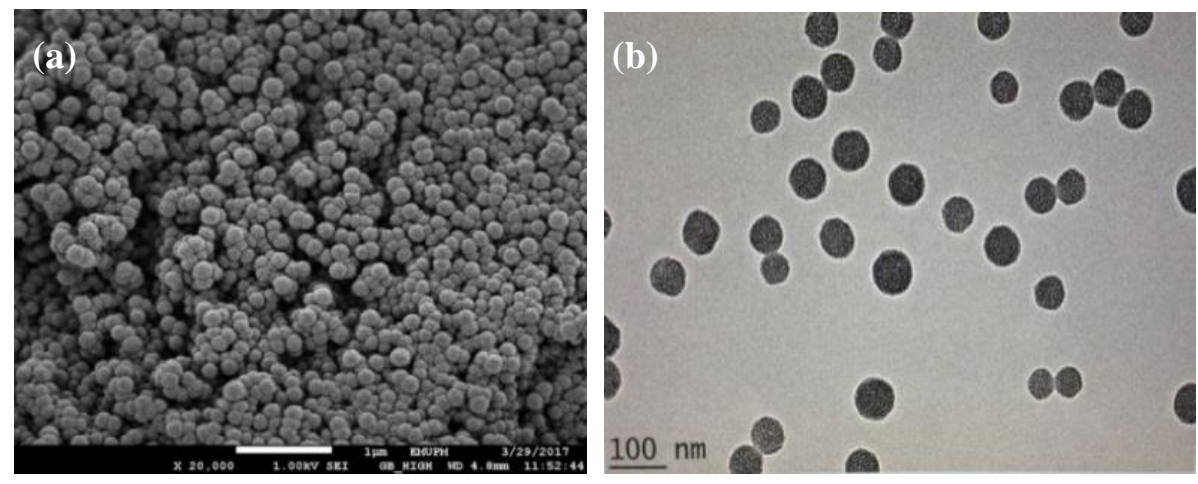
Nur Izzah et al: ELECTROSPUN POLY (VINYL ALCOHOL) NANOFIBERS DOPED WITH MESOPOROUS SILICA NANOPARTICLES FOR CONTROLLED RELEASE OF HYDROPHILIC MODEL DRUG

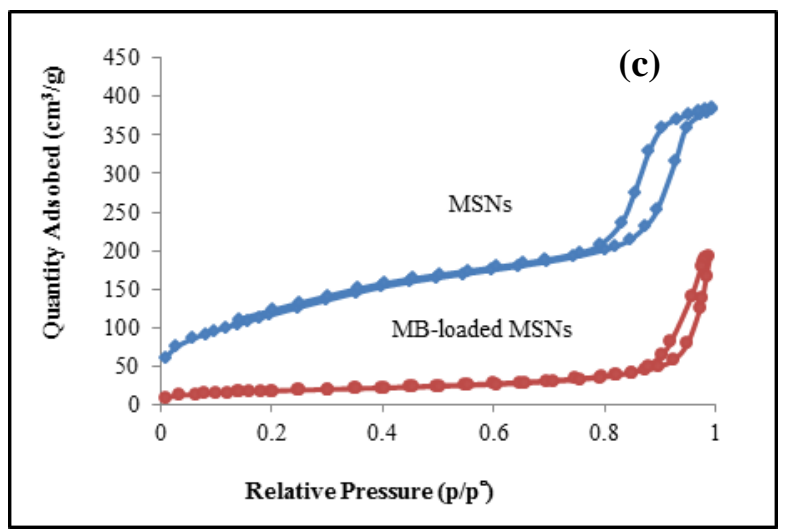

Figure 1. (a) FESEM image, (b) TEM image, and (c) nitrogen adsorption/desorption isotherms of MSNs and MBloaded MSNs

Table 1. The properties of MSNs and MSN-loaded MB, and the drug loading efficiency

\begin{tabular}{lcccc}
\hline Samples & $\begin{array}{c}\mathbf{S}_{\mathbf{B E T}} \\
\left(\mathbf{m}^{\mathbf{2}} / \mathbf{g}\right)\end{array}$ & $\begin{array}{c}\mathbf{D}_{\mathbf{P}} \\
(\mathbf{n m})\end{array}$ & $\begin{array}{c}\mathbf{V}_{\mathbf{P}} \\
\left(\mathbf{c m}_{\mathbf{3}} / \mathbf{g}\right)\end{array}$ & $\begin{array}{c}\text { Drug-loading } \\
\text { efficiency } \mathbf{( \% )}\end{array}$ \\
\hline MSNs & 429.14 & 5.5 & 0.63 & - \\
MB-loaded MSNs & 63.06 & 18.8 & 0.29 & 91.9 \\
\hline
\end{tabular}

The morphology of electrospun composite mat

The FESEM images of PVA nanofiber before and after crosslinking are shown in Figure 2(a) and (c), respectively. The morphology of PVA nanofiber before cross-linked were uniform structure with no beads, fine and oriented fibers were formed as seen in Figure 2(a). Besides, the cross-linked PVA nanofiber were displayed stiffer and robust network with some interconnection at nanofiber junction [9]. It also was observed that the average diameter of cross-linked PVA nanofiber compared with non-crosslinked nanofiber were reduced from $337 \mathrm{~nm}$ to $250 \mathrm{~nm}$, as shown in diameter distribution histograms below.
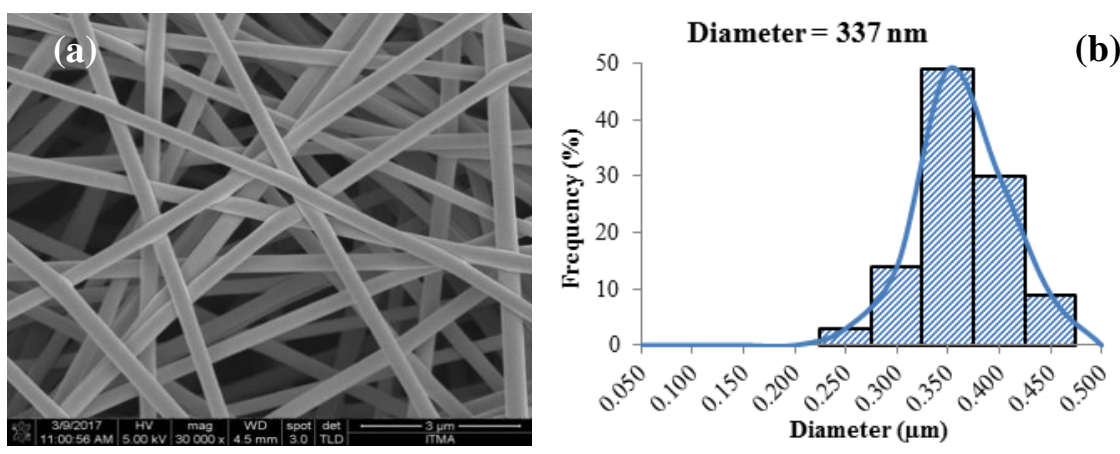

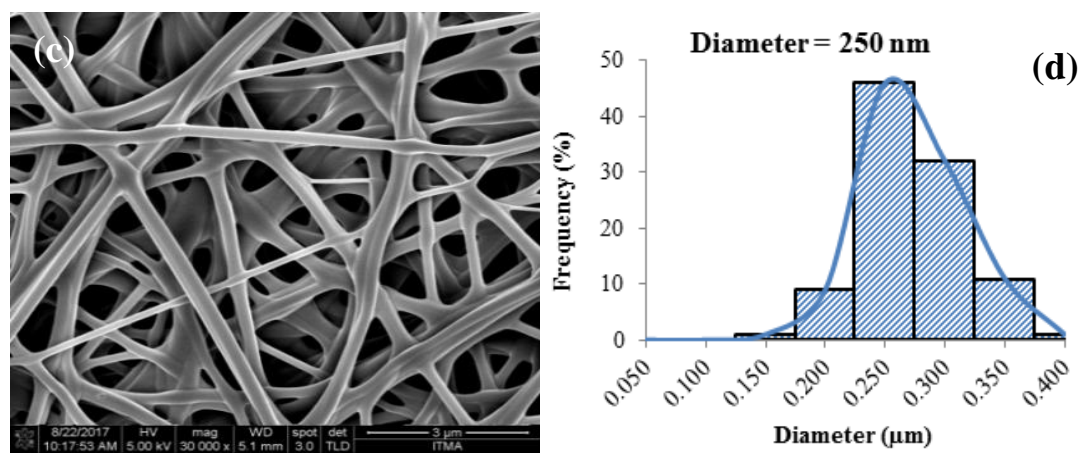

Figure 2. FESEM images of (a) non-crosslinked PVA, (c) cross-linked PVA nanofiber and (b, d) fibers diameter distribution histograms of resultant PVA nanofibers

\section{The morphology of MSNs in electrospun mat}

Figure 3 ( $a$ and $b$ ) showed FESEM images of PVA nanofiber loaded with MSNs. The figures depict that MSNs were well distributed in the PVA nanofiber. However, after addition of MSNs, the surface of electrospun PVA nanofiber seems to become rougher than electrospun without addition of MSNs. Furthermore, the average nanofiber diameter increased up to $529 \mathrm{~nm}$ in PVA-loaded MSNs electrospun mats as plotted through diameter distributions in Figure 3(c). This occurrence is due to the aggregation of MSNs in the polymer solution during electrospinning, rise in solution viscosity or incomplete dispersion during initial dispersion process into the polymer solution [6].
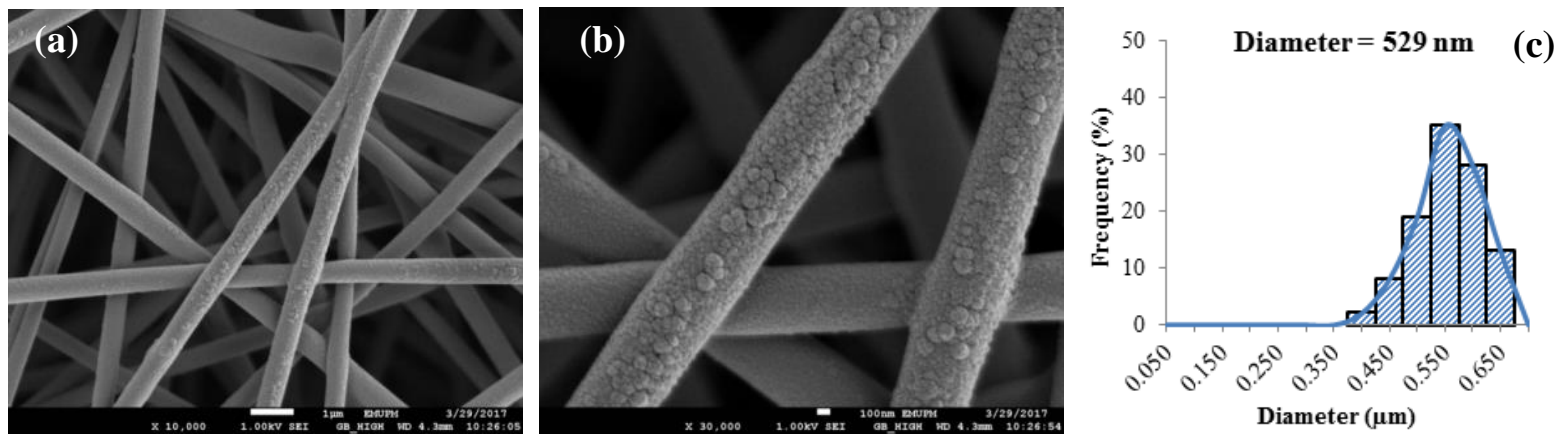

Figure 3. FESEM images of (a, b) PVA nanofiber loaded MSNs and (c) the corresponding diameter distribution histogram

The morphology of MB-loaded electrospun composite mats after releasing

The FESEM morphology of both PVA-loaded MB and the PVA-MB loaded MSNs electrospun mats after being immersed in PBS pH 7.4 for 120 hours are shown in Figure 4(a) and (c), respectively. By comparing with electrospun mats before immersing in PBS, the average fiber diameter increased because of the nanofibers were swollen in the PBS. There are several nanoparticles has been seen in the swollen nanofibers in Figure 4(c). As shown in the fiber diameter distributions in Figure 4(b) and (d), the average fiber diameter increased up to $750 \mathrm{~nm}$. This phenomenon occurred due to water molecules diffused into the polymer matrix and the interaction between the polymer chains decreased. Therefore, the polymer chains relaxed and the nanofibers swelled [10,11]. 

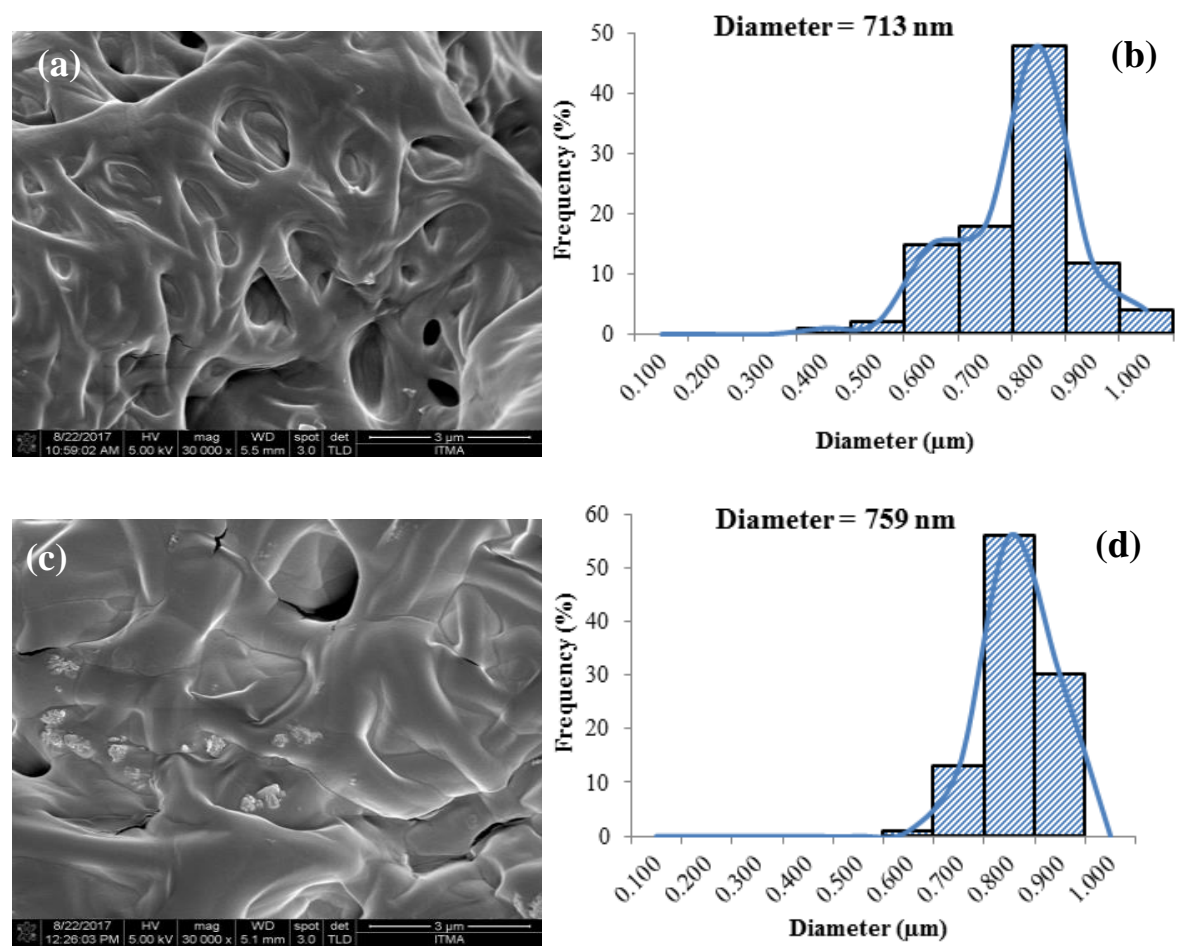

Figure 4. FESEM images of (a) PVA-loaded MB and (c) PVA-MB loaded MSNs electrospun mats after being incubated in PBS pH 7.4 for 120h, and (b,d) the corresponding fibers diameter distribution histograms

The cumulative release of MB from composite mats

The release of MB from MSNs alone and two different electrospun mats were measured by shaking in PBS solution $(\mathrm{pH}$ 7.4) at room temperature. The results as in Figure 5 showed that MB-loaded MSNs released speedily in the first 10 hours followed by fast manner with total amount of MB released nearly $90 \%$ up to 120 hours. The effect of incorporation MB-loaded MSNs in the nanofiber was investigated. The released rate of PVA-MB loaded MSNs was slowed down with $58 \%$ in the first 10 hours, followed by a sustained release up to total $76 \%$ till 120 hours. It revealed a long-term release compared to PVA-loaded MB which is without cooperation of MSNs. The presence of loaded MSNs give influences to reduce the burst release of drug [12].

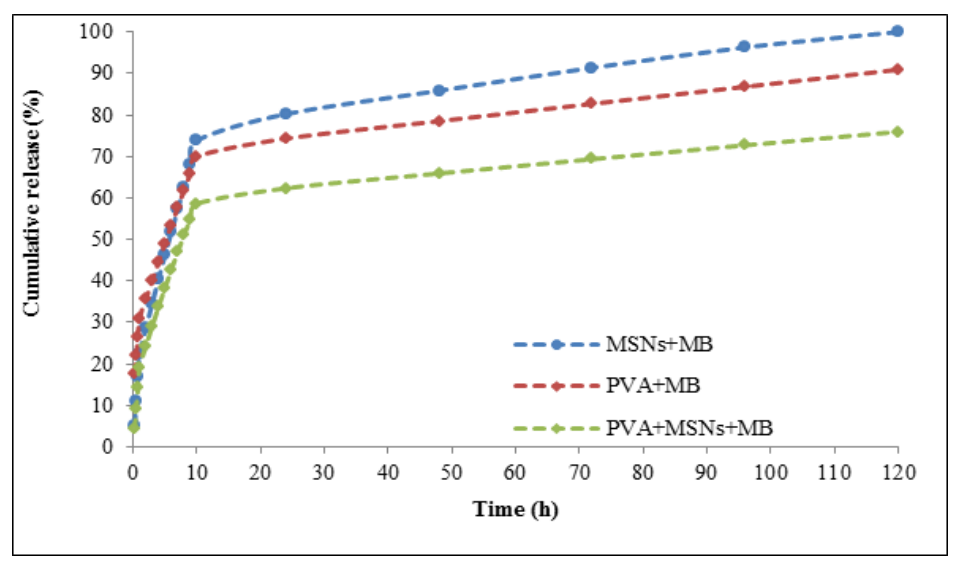

Figure 5. The cumulative MB release profile from MB-loaded MSNs, PVA/MB electrospun mats and PVA/MB loaded MSNs electrospun mats 


\section{Conclusion}

MSNs were successfully synthesized by using 1-hexadecylpyridinium bromide $\left(\mathrm{C}_{16} \mathrm{PyBr}\right) \mathrm{IL}$ as template. The incorporation and confining of MSNs into the PVA nanofiber was successfully fabricated using the technique of electrospinning, while the release studies of MB were determined. The results showed that combination of MSNsloaded MB into the nanofiber could prevent the burst release of drug as well as release in slow manner compared with the single MSNs-loaded MB. Thus, PVA/MSNs electrospun mats could be an excellent carrier for controllable delivery of drug. Therefore, it also may well be loaded with proper drugs to be applied for wound dressing. For further research, the tri-axial electrospinning technique which can fabricate up to three layers in one nanofiber and combination of different biodegradable polymers in each layer were suggested in order to achieve longer release profiles.

\section{Acknowledgement}

The authors gratefully acknowledge the Putra Grant IPS project GP-IPS/2017/9520100 from Universiti Putra Malaysia (UPM). We also would like to thank to MyBrain15 (Ministry of Higher Education) for educational scholarship scheme.

\section{References}

1. Aliabadi, H. M. and Lavasanifar, A. (2006). Polymeric micelles for drug delivery. Expert opinion on drug delivery, 3(1): $139-162$.

2. Thipparaboina, R., Chavan, R. B., Kumar, D., Modugula, S. and Shastri, N. R. (2015). Micellar carriers for the delivery of multiple therapeutic agents. Colloids and Surfaces B: Biointerfaces, 135(1): 291 -308.

3. Vahed, S. Z., Salehi, R., Davaran, S. and Sharifi, S. (2017). Liposome-based drug co-delivery systems in cancer cells. Materials Science and Engineering: C, 71(1): 1327 - 1341.

4. Goyal, R., Macri, L. K., Kaplan, H. M. and Kohn, J. (2016). Nanoparticles and nanofibers for topical drug delivery. Journal of Controlled Release, 240(1): 77 - 92.

5. Khalf, A. and Madihally, S. V. (2017). Recent advances in multiaxial electrospinning for drug delivery. European Journal of Pharmaceutics and Biopharmaceutics, 112(1): 1 - 17.

6. Jalvandi, J., White, M., Truong, Y. B., Gao, Y., Padhye, R. and Kyratzis, I. L. (2015). Release and antimicrobial activity of levofloxacin from composite mats of poly ( $\varepsilon$-caprolactone) and mesoporous silica nanoparticles fabricated by core-shell electrospinning. Journal of Materials Science, 50(24): 7967 - 7974.

7. Song, B., Wu, C. and Chang, J. (2012). Controllable delivery of hydrophilic and hydrophobic drugs from electrospun poly (lactic-co-glycolic acid)/mesoporous silica nanoparticles composite mats. Journal of Biomedical Materials Research Part B: Applied Biomaterials, 100(8): 2178 - 2186.

8. Mehrasa, M., Asadollahi, M. A., Nasri-Nasrabadi, B., Ghaedi, K., Salehi, H., Dolatshahi-Pirouz, A. and Arpanaei, A. (2016). Incorporation of mesoporous silica nanoparticles into random electrospun PLGA and PLGA/gelatin nanofibrous scaffolds enhances mechanical and cell proliferation properties. Materials Science and Engineering: $C, 66(1): 25-32$.

9. Vashisth, P. and Pruthi, V. (2016). Synthesis and characterization of crosslinked gellan/PVA nanofibers for tissue engineering application. Materials Science and Engineering: C, 67(1): $304-312$.

10. Park, C. G., Kim, E., Park, M., Park, J. H. and Choy, Y. B. (2011). A nanofibrous sheet-based system for linear delivery of nifedipine. Journal of Controlled Release, 149(3): 250 - 257.

11. Liverani, L., Lacina, J., Roether, J. A., Boccardi, E., Killian, M. S., Schmuki, P., Schubert, D. W. and Boccaccini, A. R. (2017). Incorporation of bioactive glass nanoparticles in electrospun PCL/chitosan fibers by using benign solvents. Bioactive Materials, 3(1): $55-63$.

12. Song, B., Wu, C. and Chang, J. (2012). Dual drug release from electrospun poly (lactic-co-glycolic acid)/mesoporous silica nanoparticles composite mats with distinct release profiles. Acta Biomaterialia, 8(5): $1901-1907$. 